Article

\title{
New R-Based Methodology to Optimize the Identification of Root Endophytes against Heterobasidion parviporum
}

\author{
Linda Rigerte, Kathrin Blumenstein $(\mathbb{D}$ and Eeva Terhonen * \\ Forest Pathology Research Group, Büsgen-Institute, Department of Forest Botany and Tree Physiology, Faculty \\ of Forest Sciences and Forest Ecology, University of Göttingen, Büsgenweg 2, 37077 Göttingen, Germany; \\ lindarigerte@gmail.com (L.R.); kathrin.blumenstein@uni-goettingen.de (K.B.) \\ * Correspondence: terhonen@uni-goettingen.de; Tel.: +49-0551-39-10380
}

Received: 12 March 2019; Accepted: 4 April 2019; Published: 6 April 2019

check for updates

\begin{abstract}
Many root fungal endophytes inhabiting forest trees have potential impact on the health and disease progression of certain tree species. Hence, the screening of root endophytes for their biocontrol abilities is relevant for their potential to protect their hosts against invaders. The aim of this research is to screen for the potential inhibitory effects of selected conifer root endophytes during interaction, in vitro, with the root rot pathogen, Heterobasidion parviporum. Here, we introduce a guideline that facilitates the use of root fungal endophytes as biocontrol agents. We isolated fungal root endophytes from eight different conifers. These root fungal endophytes were evaluated for their antagonism against the root rot pathogen, $H$. parviporum, by means of paired-culture antagonism assays. We determined the antagonism of the isolated root fungal endophytes to elucidate potential biocontrol applications. For the analysis, a software package in $\mathrm{R}$ was developed. Endophyte candidates with antagonistic potential were identified.
\end{abstract}

Keywords: fungal endophytes; inhibitory activity; biocontrol; forest pathogens; conifers

\section{Introduction}

Endophytes are organisms that, at some stage in their lifecycle, colonize a portion of a plant's tissue internally without causing any visible disease symptoms [1-4]. The increasing interest in plant endophyte communities is derived from their apparent potential to positively influence stress tolerance in trees, further providing new sources to be exploited in tree health protection [5]. To understand the function of root endophytes in forest trees, inoculation studies on host trees have been performed. The observed effects vary from beneficial interactions [6-10], to neutral [11], and sometimes even to pathogenic $[8,12]$. The nature of root endophyte-host interactions seems to depend on the strain of endophyte and the experimental environment [12-15]. In the context of forest pathology, the most beneficial aspect of endophytes is the production of unique secondary metabolites, which may limit pathogen growth $[6-8,16,17]$. Tellenbach and Sieber [6] isolated compounds from Phialocephala europaea, of which, sclerin and sclerotinin A were demonstrated to significantly reduce the growth of Phytophtora citricola sensu lato. Similarly, Terhonen et al. [8] found that metabolites extracted from liquid cultures of root endophytes, Phialocephala sphareoides and Cryptosporiopsis sp., inhibit the growth of several plant pathogens (Heterobasidion parviporum, Phytophtora pini, and Botrytis cinerea). Fungal endophytes can also decrease the infections of pathogens in their host roots, which can be observed in a study conducted by Tellenbach and Sieber [6], who showed that some strains of Phialocephala subalbina could reduce disease severity caused by the two oomycete root rot pathogens, Elongisporangium undulatum and Phytophtora plurivora, in Norway spruce seedlings. Terhonen et al. [8] demonstrated that the root endophyte, $P$. 
sphareoides, was able to prevent the infections of Norway spruce seedling roots by the pathogen, $H$. parviporum, in vitro. Indeed, fungal endophytes might play an important role in ecosystem dynamics, affecting not just the fitness of the specific host plant, but also the overall structure and well-being of tree communities [5]. This is supported by the fact that entire assemblages of endophytes have adapted to specialized habitats along with their hosts; for example, aquatic fungi that inhabit submerged plant roots [18].

The dominating group of root endophytes in tree roots are the 'dark septate endophytes' (DSEs) [15,19-27]. DSEs feature a very characteristic darkly pigmented ("melanized") hyphal growth inside roots $[9,16]$. The Phialocephala fortinii s.l-Acephala applanata species complex (PAC) is the dominant group of DSEs and they are among the best-characterized DSEs [15,25,28-32]. Members of the PAC species complex are cryptic and they are very widespread and abundant in roots of conifers and ericaceous plants $[15,19,20,23-25,27]$. Generally, DSEs do not seem to have host specificity; however, there are some species that seem to prefer certain host taxa and some of the PAC species preferentially occur on the Pinaceae family $[15,19-21,24,33,34]$.

Heterobasidion annosum sensu lato (s.1.) is the main cause of the root rot of conifers in Europe [35-38]. The H. annosum s.l. complex in Europe consists of three native species: H. annosum sensu stricto, H. parviporum, and H. abietinum $[35,39,40]$. Of these, $H$. parviporum is the major pathogen for the economically important conifer, Norway spruce (Picea abies). H. parviporum infects the tree through deposition of airborne basidiospores on freshly cut stumps, where infection can easily initiate [41-43]. As the infection progresses, wood material is rapidly colonized by H. parviporum. After the infection is established, Heterobasidion species can remain viable in these stumps for decades [44], resulting in an inoculum source for new tree generations [43-45] by spreading through root contacts to neighbouring trees $[45,46]$. In addition, as $H$. parviporum can remain undetected in the host tree for many years, the risk of $H$. parviporum infecting neighbouring healthy trees via root contacts increases [43-46]. As such, in search of control measures against $H$. parviporum, one interesting direction to pursue is the study of root endophytes. The possible inhibitory effect of root endophytes on root pathogens, such as H. parviporum, can be harnessed for potential biocontrol applications. These kinds of fungi could be used in infected sites to protect the roots of newly planted seedlings. Terhonen et al. [19] demonstrated that $17 \%$ of root endophytes isolated from a spruce-dominated site are capable of inhibiting the growth of H. parviporum. Particularly, the root endophyte, P. sphareoides, not only inhibits the necrotrophic H. parviporum, but also promotes host growth and health [8]. However, the ecological and potential functional role of these abundant endophytic fungi in the host-endophyte interaction remains largely unexplored.

In this study, the root fungal endophytes of eight conifer tree species from the Forest Botanical Garden of the University of Göttingen (Germany) were isolated and tested for their antagonistic reaction against $H$. parviporum. The identities and phylogeny of the isolated root endophytes were established on the basis of their internal transcribed spacer (ITS) region sequences. The antagonism of the endophytes to $H$. parviporum was investigated by dual culture assays on agar media. This work aims to determine the antagonism of the isolated root endophytes and elucidate potential biocontrol applications within the contextual constraints described in the sections above. It also aims to evaluate the potential inhibitory effect of a subset of the isolated endophytes on the pathogen, H. parviporum. To analyse this, a software package in $\mathrm{R}$ was developed.

\section{Materials and Methods}

Fine root samples were collected in early January 2018 from mature conifer trees with no visible disease symptoms in the Forest Botanical Garden, Göttingen, Germany ( $\left.51^{\circ} 33^{\prime} 26.55^{\prime \prime} \mathrm{N} / 9^{\circ} 57^{\prime} 40.72^{\prime \prime} \mathrm{E}\right)$. A simple random sampling pattern was applied for tree selection to minimize sampling bias. Fine roots from conifer hosts exhibiting no visible signs of mycorrhizae were collected, placed in Falcon tubes, and stored at $-20^{\circ} \mathrm{C}$. Eight different conifer species were sampled. Overall, only one tree was sampled each for Picea pungens, Picea sitzenchis, and Pinus peuce, two trees each for Picea omorika, Picea glauca, and Pinus jeffreyi, and three trees each for P. abies and Pinus sylvestris (Table 1). 
Table 1. List of sampled host conifers, their common names, native ranges, and sample abbreviations used in the data.

\begin{tabular}{cccc}
\hline Host Species & Common Name & Native to & Abbreviation \\
\hline Picea abies & Norway spruce & Northern, Central, and Eastern Europe & Abie \\
Picea glauca & White/Canadian spruce & Alaska through central Canada to Newfoundland & Glau \\
Picea omorika & Serbian spruce & Endemic to Drina river valley, Serbia & Omori \\
Picea pungens & Blue/Colorado spruce & Rocky Mountains, USA & Pung \\
Picea sitchensis & Sitka spruce & West coast Canada, down to California & Sitch \\
Pinus jeffreyi & Jeffrey pine & Oregon-California, USA & Jeff \\
Pinus peuce & Macedonian/Balkan pine & Mountains of Balkan region & Peuc \\
Pinus sylvestris & Scots pine & Eurasia & Sylv \\
\hline
\end{tabular}

The collected fine roots were processed in $24 \mathrm{~h}$. First, they were washed under running tap water to remove soil particles and cut into small pieces. Root segments were disinfected in $99 \%$ ethanol $\left(\mathrm{C}_{2} \mathrm{H}_{5} \mathrm{OH}\right)$ for $1 \mathrm{~min}, 2 \%$ sodium hypochlorite $(\mathrm{NaOCl})$ for $3 \mathrm{~min}$, followed by $70 \%$ ethanol for $1 \mathrm{~min}$; the roots were then rinsed in autoclaved ultrapure water $\mathrm{H}_{2} \mathrm{O}$ for 3 to 5 times. The surface sterilized roots were placed on 1.5\% malt agar plates (MEA) and Modified Melin-Norkrans medium (MMN) plates [47]. The MMN plates were composed as follows: $0.066 \mathrm{~g} \mathrm{CaCl}_{2} \mathrm{X}_{2} \mathrm{H}_{2} \mathrm{O}$ (calcium chloride

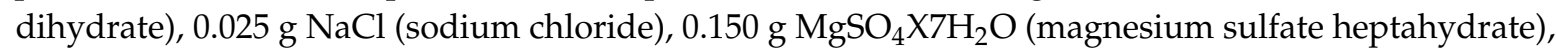
$0.500 \mathrm{~g} \mathrm{NH}_{4}\left(\mathrm{H}_{2} \mathrm{PO}_{4}\right)$ (ammonium dihydrogen phosphate), $0.500 \mathrm{~g} \mathrm{KH}_{2} \mathrm{PO}_{4}$ (potassium dihydrogen

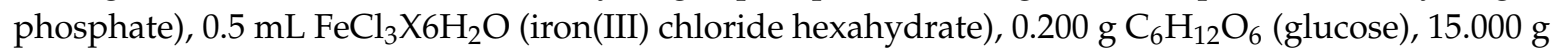
agar, and $0.5 \mathrm{~mL}$ thiamine- $\mathrm{HCl}$ dissolved in $1000 \mathrm{~mL}$ distilled water ( $\mathrm{pH}$ of 5.5-5.8). Altogether, three short root tip segments from each sample tube were placed in MEA and MMN plates. The plates were incubated in darkness at $19{ }^{\circ} \mathrm{C}$ with $75 \%$ relative humidity. The incubation period necessary for the growth of various root endophytes differed between plates, ranging from 14 days to one month. When the growth of a root endophyte was observed, a small piece of the hyphae was transferred as a pure culture. Sixty-five (65) root endophytes were isolated, and grouped together based on their morphological features to 19 different groups; 1 to 3 members of each group were then chosen for molecular identification (28 samples).

DNA of fungal endophytes was extracted from $150 \mathrm{mg}$ of the homogenized mycelium sample using the "innuPREP Plant DNA Kit" (Analytik Jena AG, Jena, Germany), according to the manufacturer's instructions. Taq DNA polymerase (Qiagen, Hilden, Germany) was used for PCR amplification of ITS regions with the primer pair, ITS1-F and ITS4 [48]. Briefly, the PCR protocol was as follows: 1X CoralLoad PCR Buffer, $200 \mu \mathrm{M}$ dNTP, $0.5 \mu \mathrm{M}$ primer 1, $0.5 \mu \mathrm{M}$ primer 2, 100 ng template DNA, and $0.2 \mathrm{U} / \mu \mathrm{L}$ DNA polymerase; the reaction was adjusted to $25 \mu \mathrm{L}$ with autoclaved MQ H2O. Thermocycler parameters were as follows: Initial denaturation at $95^{\circ} \mathrm{C}$ for $3 \mathrm{~min}$, followed by 15 cycles of: denaturation at $95^{\circ} \mathrm{C}$ for $30 \mathrm{~s}$, annealing at $55^{\circ} \mathrm{C}$ for $1 \mathrm{~min}$, extension at $72^{\circ} \mathrm{C}$ for $1 \mathrm{~min} ; 15$ cycles of: denaturation at $95^{\circ} \mathrm{C}$ for $30 \mathrm{~s}$, annealing at $63^{\circ} \mathrm{C}$ for $1 \mathrm{~min}$, extension at $72{ }^{\circ} \mathrm{C}$ for $1 \mathrm{~min}$; final extension at $72{ }^{\circ} \mathrm{C}$ for $10 \mathrm{~min}$ and held at $4{ }^{\circ} \mathrm{C}$ indefinitely. The quality of the obtained PCR products was checked on $1 \%$ agarose gel (with GelRed nucleic acid stain) under UV illumination. Sequencing was performed with ITS4 primer at Microsynth SEQLAB (Göttingen, Germany). For 24 samples, the full coverage of the ITS1-5.8S-ITS2 region was achieved.

The ITS1 and ITS2 regions of all sequenced samples were extracted using the ITSx program [49]. New sequences consisting of ITS1 to ITS2 regions were constructed-concatenation was performed using the sequence concatenation tool available in MEGA X [50]. Sequence identity was established through a search for homology using the National Center for Biotechnology Information's (NCBI) Basic Local Search Alignment Tool (BLAST) [51]. The top three matches for each sequence were selected based on query coverage $(\mathrm{QC})$ and identity $(\mathrm{Mi} \%)$ with regional proximity acting as a tiebreaker in case of conflicts. Of these, only the match that had the best coverage and identity was selected as the homolog establishing positive identification of the sample. The homologous sequences were downloaded as an unaligned FASTA file. The concatenated ITS1 to ITS2 regions and their BLAST 
matches were aligned using MAFFT [52]; alignment parameters were determined automatically by the program (-auto command). The final dataset consisted of 41 nucleotide sequences ( 24 samples, 16 references, and 1 outgroup sequence) with 635 positions (inclusive of gaps). The Kimura 2-parameter model [53] with gamma distributed rates ( 5 rate categories; $G=1.915$ ) and a proportion of invariant sites $(I=0.032)$ was selected to model the evolution of the sequences on the basis of its lowest negative $\log$ likelihood score $(-\ln L=-4987.465)$ in comparison to the evaluated fits for all other models available in MEGA X (evaluated using MEGA X's internal model selection tool). The initial tree(s) for the ML phylogeny was/were obtained automatically by applying Neighbor-Joining (NJ) and BioNJ algorithms to a matrix of pairwise distances estimated using the maximum composite likelihood (MCL) approach, and then selecting the topology/topologies with superior log likelihood value(s). Molecular phylogeny was established by means of maximum likelihood (ML) analysis with 1000 bootstrap replicates in MEGA X [50,54]. Final adjustments to the generated ML tree were performed in TreeGraph2 [55] and Microsoft PowerPoint. The ITS1 sequences used in BLAST searches were deposited to GenBank with the following accession numbers, MK589294-MK589317.

The antagonism of the isolated root endophyte against the pathogen, $H$. parviporum, was investigated by means of a paired-growth assay. The ability of a root endophyte to antagonize the pathogen was determined based on the inhibition level over a given period of time. This was achieved by assessing and measuring the concurrent growth of both the endophyte and the pathogen simultaneously on a shared 1.5\% MEA nutrient media surface (Figure 1).

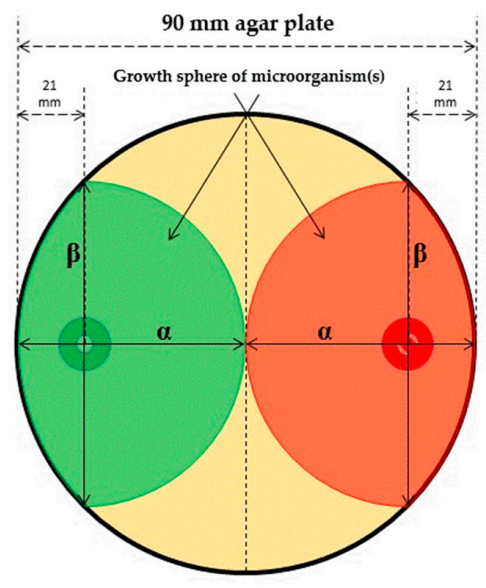

Dual-culture antagonism assay

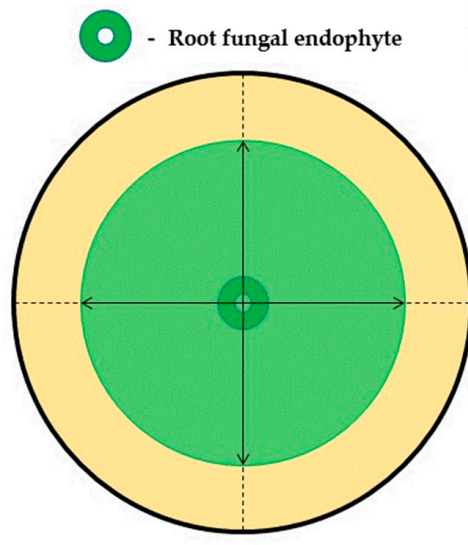

Root endophyte growth, control

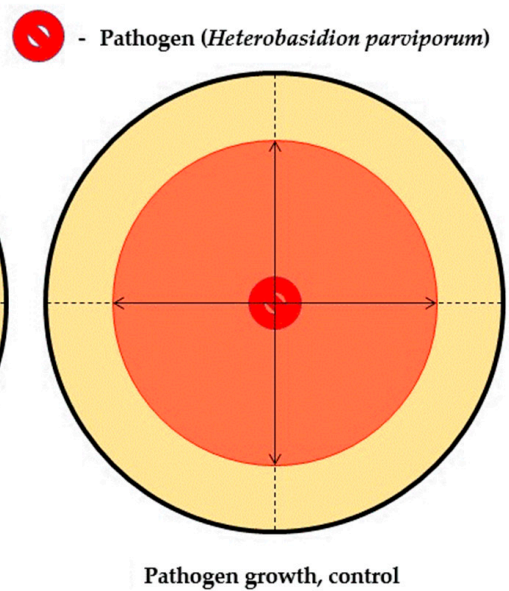

Pathogen growth, control

Figure 1. Schematic overview of the setup of the antagonism assay. The dual-culture antagonism assay tests the inhibitory effect of the root fungal endophyte on the pathogen, Heterobasidion parviporum; the inhibitory effect is reflected in spherical index $(\alpha / \beta)$ of the respective organisms. Solitary cultures of the respective root endophyte and the pathogen were also plated-and observed-as controls in this experiment.

The antagonistic tests were conducted in the form of dual-culture assays pairing a root fungal endophyte with the pathogen (Figure 1). The root endophyte and pathogen were placed colinear on the surface of malt agar plates $(\mathrm{pH}=6)$ within a distance of $2.1 \mathrm{~cm}$ from the perimeter of the petri dish. Such pairings were generated in triplicates for statistical rigor. For each pair of endophyte and pathogen, a control plate containing a single solitary endophyte (spotted identically on the plate as to the paired setup) was also prepared as the endophyte growth control; each endophyte received three controls. Control plates to monitor the pathogen's growth were also prepared in an identical manner (12 replicates in total). All these plates were then incubated under the same conditions to stimulate the growth of the resident microorganisms (darkness, humidity $75 \%, 19{ }^{\circ} \mathrm{C}$ ). Growth measurements were taken 3, 7, and 10 days after inoculation. Measurements were performed for both the root endophytes as well as the pathogen in the antagonism test plate (Figure 2). All isolated endophytes 
participated in the antagonism assay(s). The measured parameters were the major $(\alpha)$ and minor $(\beta)$ axes of progression along the colinear axis joining the original spotting locations of the endophyte and/or pathogen. In theory, $\alpha$ measures the progression of the antagonists towards one another (and conversely indicates a measure of the antagonistic effect) while $\beta$ measures the orthogonal progression (i.e., to $\alpha$ ) of the antagonists over the available surface area (an indirect measure of competitive spread). The ratio, $\alpha / \beta$, is the spherical index, which is considered a measure of the antagonism exhibited by the endophyte and pathogen against one another [56,57]. The reasoning is that an organism growing in isolation on a circular surface would grow uninhibited radially outwards from the site of inoculation - this corresponds to a spherical index of 1 (since $\alpha=\beta$ ). Therefore, should an inhibitory source be present, radial progression in that particular direction would be negated or minimized, and the spherical index would no longer equal 1 (since $\alpha \neq \beta$ ). In this regard, a spherical index $>1$ (for the endophyte) indicates that the endophyte is inhibiting the pathogen, and an index $<1$ indicates it has minimal or no inhibitory effect. Conversely, a spherical index $<1$ for the pathogen indicates that it is being (successfully) antagonized by the endophyte, while a spherical index $>1$ indicates the endophyte has no effect on the pathogen's growth or existence. This data included observations under the aforementioned variables for unique endophyte samples $(n=65)$ at every point of measurement $(3$, 7 , and 10 days, respectively) for a total of 195 measurements. This resulted in a large raw dataset to be screened for the identification of successful fungal antagonists to H. parviporum. Thus, a filtering process was necessary, and data filtering pipeline was implemented in $\mathrm{R}$ to mitigate this challenge; the filtering logic as well as the pipeline are briefly described below.

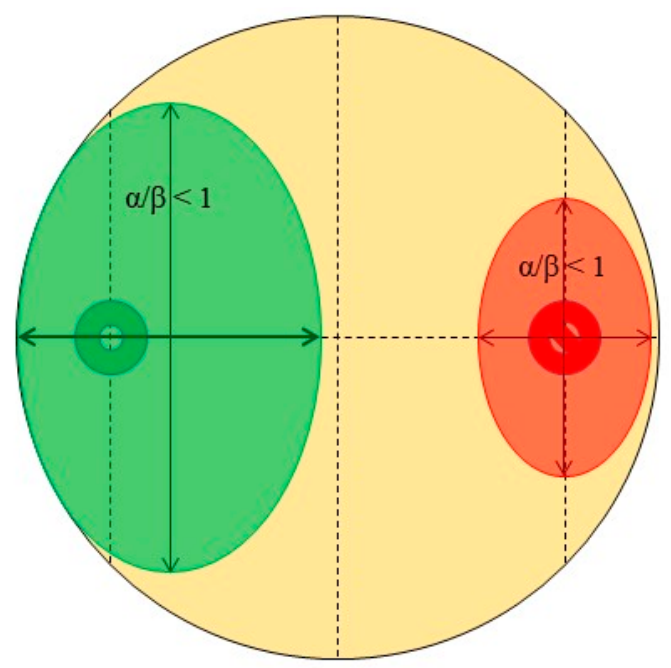

Figure 2. Example schematic antagonism assay plate where both the endophyte antagonist (green) as well as the pathogen (red) have a spherical index $<1$.

The explanation provided earlier in this section concerning the spherical index of the root endophyte or the pathogen alone, as a determinant of the fungus' antagonistic effectiveness against the pathogen, is a naïve interpretation of this number. The spherical index is a ratio resulting from measurements specific to the organism only (and not its surroundings or context), which cannot provide reliable information on the effects of biotic or abiotic factors upon the test organism (nor vice versa) even with replication and statistical testing. For example, consider the case presented in Figure 2: If successful antagonism were indicated only by the spherical index of the endophyte, then this would be an unsuccessful case; conversely, if it were indicated by the spherical index of the pathogen only, then this would be considered a successful case. In truth, it is neither, as neither the antagonist nor the pathogen have grown considerably towards one another. The problem lies in the fact that even under the best-optimized control conditions, biological organisms do not grow evenly nor predictably. In this context, the only way to distinguish a case of an actual, successful antagonism from a spurious one is 
by considering the spherical ratios of both the antagonist endophyte as well as the pathogen. It can be stated that true antagonism in the experimental conditions described in this section only occurs when the spherical indices indicate that the growth of the endophyte antagonist along the colinear axis (joining the locations of the inoculates of the antagonist and the pathogen) is greater than its growth orthogonal to the colinear axis and also the growth of the pathogen along the colinear axis is less than its growth orthogonal to this axis.

This is illustrated in Figure 3 using simulated data (mimicking actual observations). Each data point presented in Figure 3 corresponds to a spherical index pair (X-axis-spherical index of root endophyte, Y-axis-spherical index of pathogen). In Figure 3, the logic described in the paragraphs above corresponds to the unshaded quadrant occupied by the green coloured data points in Figure 3 (pathogen, $\alpha / \beta<1$ and endophyte, $\alpha / \beta>1$; quadrant 4). The data points of every other quadrant can be considered spurious in the context of them being indicative of antagonism from the endophyte to the pathogen.

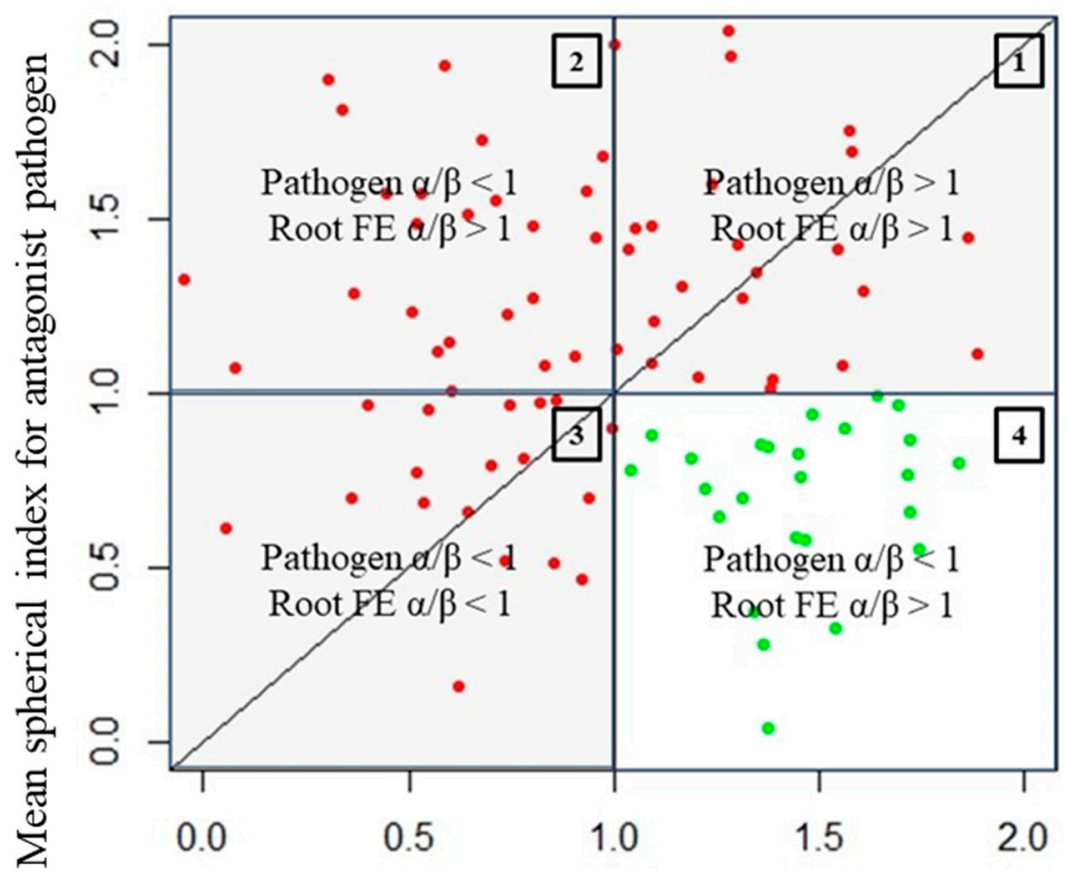

Mean spherical index for antagonist fungal endophyte

Figure 3. A graph of the mean spherical indices of a set of root fungal endophyte (FE) antagonists plotted against their single test pathogen. This is a simulated dataset generated from a random distribution $(n=100$, mean $=1$, standard deviation $=0.5)$ that mimics empirical data observed in this experiment. In the graph above, the data points coloured green are non-spurious instances of successful antagonistic interaction while the red data points indicate spurious ones.

The reasoning is as follows:

1. Quadrant described by pathogen, $\alpha / \beta>1$, and endophyte, $\alpha / \beta>1$ (quadrant 1): There is clearly no antagonism occurring in these samples as the growth of neither organism along the colinear axis appears to be suppressed or prohibited.

2. Quadrant described by pathogen, $\alpha / \beta>1$, and endophyte, $\alpha / \beta<1$ (quadrant 2): The root endophytes described by their datapoints in this quadrant likely have no effect on the growth of the pathogen (or may conversely even be getting suppressed by the pathogen themselves) as its progression along the colinear axis is higher in comparison to its orthogonal spread and also higher in comparison to the progression of the antagonist along the colinear axis itself. 
3. Quadrant described by pathogen, $\alpha / \beta<1$, and endophyte, $\alpha / \beta<1$ (quadrant 3): There is likely no interaction at all between the root endophytes and the pathogen in the cases described by this quadrant as both spherical indices are less than 1 ; this likely indicates purely natural growth with no antagonistic effects taking place.

Thus, for analysis of this dataset, a short filtering pipeline was constructed in R to select only those samples that met the above-mentioned criteria for consideration as instances of true antagonism (pathogen $\alpha / \beta<1$ and endophyte $\alpha / \beta>1$ ). The code for the pipeline as well as the statistics are presented in the appendix (Supplementary Files 1 and 2). The means and standard deviations of the pathogen spherical indices and the endophyte spherical indices ('PRabMean', 'PRabSD', 'FRabMean', and 'FRabSD' of the 3 replicates each) were first calculated and fed into this pipeline to filter out observations that did not match the selection criteria (pathogen $\alpha / \beta<1$ and endophyte $\alpha / \beta>1$ ). The original raw dataset was then subdivided into subsets consisting of raw observations (i.e., individual replicate-level observations) from day 3, day 7, and day 10, respectively (Supplementary File 2), consisting of only the selected observations, which were then used for comparative statistics. Comparative statistics involved the 12 pathogen control replicates and the triplicate measurements of the pathogen's spherical index from the antagonism assays-since the data had already been filtered for spurious measurements, this comparison would be strongly indicative of the presence of actual antagonist endophytes in the testing regime. Comparisons were achieved by means of an unpaired t-test accounting for inequality in the variances of the sample populations (as sample sizes were unequal). The confidence interval for the test statistic was set to $95 \%$. The means of the spherical indices of different groupings of the test data were then tested against the controls. The groupings were: All root endophytes common to a specific tree host, and only the triplicates of individual endophytes.

The null hypothesis was formulated as follows: The difference between the means of the spherical indices of pathogens under antagonism (S1) and the means of the spherical indices of pathogen controls (S2) is zero (i.e., S1-S2 =0). The alternative hypothesis was formulated as follows: The difference between the means of the spherical indices of pathogens under antagonism (S1) and the means of the spherical indices of pathogen controls (S2) is less than zero (i.e., S1-S2 $<0$ ). The rationale for assuming this alternative hypothesis was that the spherical index of the pathogen under antagonism would be less than one $(<1)$ while the controls, having grown in the absence of any biotic/abiotic pressure(s), should have a spherical index $\approx 1$. Thus, if the effect (i.e., antagonism from that specific endophyte) is real, then the means would also record the same behaviour, and the subtraction of the means of controls from the pathogen replicates involved in the test would then be a negative number (i.e., less than 0 ). The results of the statistical analysis were then evaluated in the context of the other findings obtained in this study.

\section{Results}

\subsection{Identification and Diversity of Root Endophytes}

A total of 65-root endophytes were obtained from eight coniferous hosts and grouped to 19 different groups based on their morphological differences (Tables 2 and 3). Only P. pungens did not yield any isolates. 
Table 2. The isolated fungal root endophytes' frequency by tree host species.

\begin{tabular}{|c|c|c|c|c|c|c|c|c|c|c|c|}
\hline \multirow{2}{*}{ Identification } & \multirow{2}{*}{$\begin{array}{l}\text { Best Match } \\
\text { Accession no. }\end{array}$} & \multirow{2}{*}{ Order } & \multirow{2}{*}{ Class } & \multicolumn{4}{|c|}{ Picea } & \multicolumn{3}{|c|}{ Pinus } & \multirow{2}{*}{ Sun } \\
\hline & & & & abies & glauca & omorika & sitchensis & jeffreyi & peuce & sylvestris & \\
\hline Pseudogymnoascus sp. & MH857254 & $\begin{array}{c}\text { Incertae } \\
\text { sedis }\end{array}$ & Ascomycetes & & & & & & 1 & & 1 \\
\hline Cladosporium sp. & MH863129 & Capnodiales & Dothideomycetes & & & & & 2 & & & 2 \\
\hline Pyrenochaeta sp. & KT269928 & Pleosporales & Dothideomycetes & 52 & & & 4 & & & & 6 \\
\hline Pyrenochaeta sp. & LT821390 & Pleosporales & Dothideomycetes & & 1 & & & 7 & & & 8 \\
\hline Penicillium sp. & MG821367 & Eurotiales & Eurotiomycetes & & & 1 & & & & & 1 \\
\hline Penicillium sp. & MH865458 & Eurotiales & Eurotiomycetes & & & 1 & & & & & 1 \\
\hline $\mathrm{PAC}^{\mathrm{b}}$ & AY606286 & Helotiales & Leotiomycetes & & & 1 & & & & & 1 \\
\hline Fungal sp. & KY322665 & NA & NA & & & 2 & & & & & 2 \\
\hline Pezizales sp. & MH859398 & Pezizales & Pezizomycetes & & & & & & & 1 & 1 \\
\hline Clonostachys sp. & KY977560 & Hypocreales & Sordariomycetes & 3 & & & & & & & 3 \\
\hline Dactylonectria sp. & MH865183 & Hypocreales & Sordariomycetes & & 8 & & & & 1 & & 9 \\
\hline Fusarium sp. & MG252283 & Hypocreales & Sordariomycetes & & & 2 & & 6 & & & 8 \\
\hline Fusarium sp. & MG704912 & Hypocreales & Sordariomycetes & 2 & & & & & & & 2 \\
\hline Ilyonectria sp. & MH865177 & Hypocreales & Sordariomycetes & 1 & & 2 & & & & & 3 \\
\hline Trichoderma sp. & MH930456 & Hypocreales & Sordariomycetes & & & & & & & 5 & 5 \\
\hline Unknown & & NA & NA & & & & 6 & & & & 6 \\
\hline Unknown & & NA & NA & & & & & 2 & & & 2 \\
\hline Unknown & & NA & NA & & & & & 1 & & & 1 \\
\hline \multirow[t]{2}{*}{ Unknown } & & NA & NA & 3 & & & & & & & 3 \\
\hline & & & TOTAL & 11 & 9 & 9 & 10 & 18 & 2 & 6 & 65 \\
\hline
\end{tabular}

${ }^{\mathrm{b}}$ PAC: Phialocephala fortinii s.l.-Acephala applanata species complex. 
Table 3. Sequenced root endophytes and their best matches in the National Center for Biotechnology Information (NCBI) database based on concatenated internal transcribed spacer (ITS1-ITS2) sequences. The samples are grouped according to host tree species, and the GenBank accession numbers, sequence similarity (maximum identity/query coverage), as well as region of the homologous sequences used to establish molecular identity are shown.

\begin{tabular}{|c|c|c|c|c|c|c|}
\hline Sample ID & Host & Best Match & Accession & $\mathrm{Mi} / \mathrm{Qc}^{\mathrm{a}}$ & Region & Our Definition \\
\hline Abie23 & Picea abies & Clonostachys candelabrum & KY977560 & $100 / 100$ & Croatia & Clonostachys sp. \\
\hline Abie26 & Picea abies & Fusarium tricinctum & MG704912 & $100 / 099$ & S. Korea & Fusarium sp. \\
\hline Abie27 & Picea abies & Pyrenochaeta sp. & KT269928 & 099/100 & Greece & Pyrenochaeta sp. \\
\hline Glau13 & Picea glauca & Dactylonectria torresensis & MH865183 & 098/100 & Portugal & Dactylonectria sp. \\
\hline Glau17 & Picea glauca & Dactylonectria torresensis & MH865183 & 099/100 & Portugal & Dactylonectria sp. \\
\hline Glau18 & Picea glauca & Pyrenochaeta inflorescentiae & LT821390 & 099/100 & Germany & Pyrenochaeta sp. \\
\hline Glau21 & Picea glauca & Dactylonectria torresensis & MH865183 & $100 / 100$ & Portugal & Dactylonectria sp. \\
\hline Jeff49 & Pinus jeffreyi & Fusarium solani & MG252283 & 099/100 & China & Fusarium sp. \\
\hline Jeff51 & Pinus jeffreyi & Pyrenochaeta inflorescentiae & LT821390 & $099 / 100$ & Germany & Pyrenochaeta sp. \\
\hline Jeff56 & Pinus jeffreyi & Cladosporium subinflatum & MH863129 & 099/100 & Slovenia & Cladosporium sp. \\
\hline Jeff59 & Pinus jeffreyi & Pyrenochaeta inflorescentiae & LT821390 & 099/100 & Germany & Pyrenochaeta sp. \\
\hline Jeff60 & Pinus jeffreyi & Pyrenochaeta inflorescentiae & LT821390 & $099 / 100$ & Germany & Pyrenochaeta sp. \\
\hline Jeff61 & Pinus jeffreyi & Pyrenochaeta inflorescentiae & LT821390 & 099/100 & Germany & Pyrenochaeta sp. \\
\hline Jeff65 & Pinus jeffreyi & Pyrenochaeta inflorescentiae & LT821390 & 099/100 & Germany & Pyrenochaeta sp. \\
\hline Omori01 & Picea omorika & Penicillium glandicola & MG821367 & 099/100 & Italy & Penicillium sp. \\
\hline Omori02 & Picea omorika & Penicillium granulatum & MH865458 & $099 / 100$ & USA & Penicillium sp. \\
\hline Omori03 & Picea omorika & Fungal sp. KK15 & KY322665 & $099 / 100$ & Montenegro & NA \\
\hline Omori07 & Picea omorika & Phialocephala fortinii & AY606286 & 099/100 & Sweden & $\mathrm{PAC}^{\mathrm{b}}$ \\
\hline Omori08 & Picea omorika & Ilyonectria lusitanica & MH865177 & 099/100 & Portugal & Ilyonectria sp. \\
\hline Peuc68 & Pinus peuce & Dactylonectria torresensis & MH865183 & $100 / 100$ & Portugal & Dactylonectria sp. \\
\hline Peuc69 & Pinus peuce & Pseudogymnoascus pannorum & MH857254 & $100 / 100$ & Germany & Pseudogymnoascus sp. \\
\hline Sylv36 & Pinus sylvestris & Trichoderma koningii & MH930456 & 099/100 & Spain & Trichoderma sp. \\
\hline Sylv37 & Pinus sylvestris & Trichoderma koningii & MH930456 & $099 / 100$ & Spain & Trichoderma sp. \\
\hline Sylv38 & Pinus sylvestris & Ascobolus lineolatus & MH859398 & 097/099 & Tanzania & Pezizales sp. \\
\hline
\end{tabular}

${ }^{a}$ Mi/Qc: Match identity (\%)/Query coverace (\%); ${ }^{\mathrm{b}}$ PAC: Phialocephala fortinii s.l. - Acephala applanata species complex. 
The Helotiales sample (Omori07) was identified to be a member of the Phialocephala fortinii s.l.-Acephala applanata species complex (PAC). The sample, Peuc69, was positively identified as a Pseudogymnoascus sp. (100\% query coverage and 100\% concatenated ITS sequence similarity), but the precise placement of this taxon within the class, Ascomycetes, remains unresolved (Incertae sedis). Although the sample, Sylv38, only had relatively low query coverage and sequence similarity $(99 \%$ and 97\%, respectively, Table 3), potentially being identified as Ascobolus sp., the ML tree firmly established it as belonging to the Pezizales clade (Figure 4). The placements of the root endophytes from the various host trees within the phylogenetic space appears to be freely intermixed, with no readily apparent preferential patterns visible.

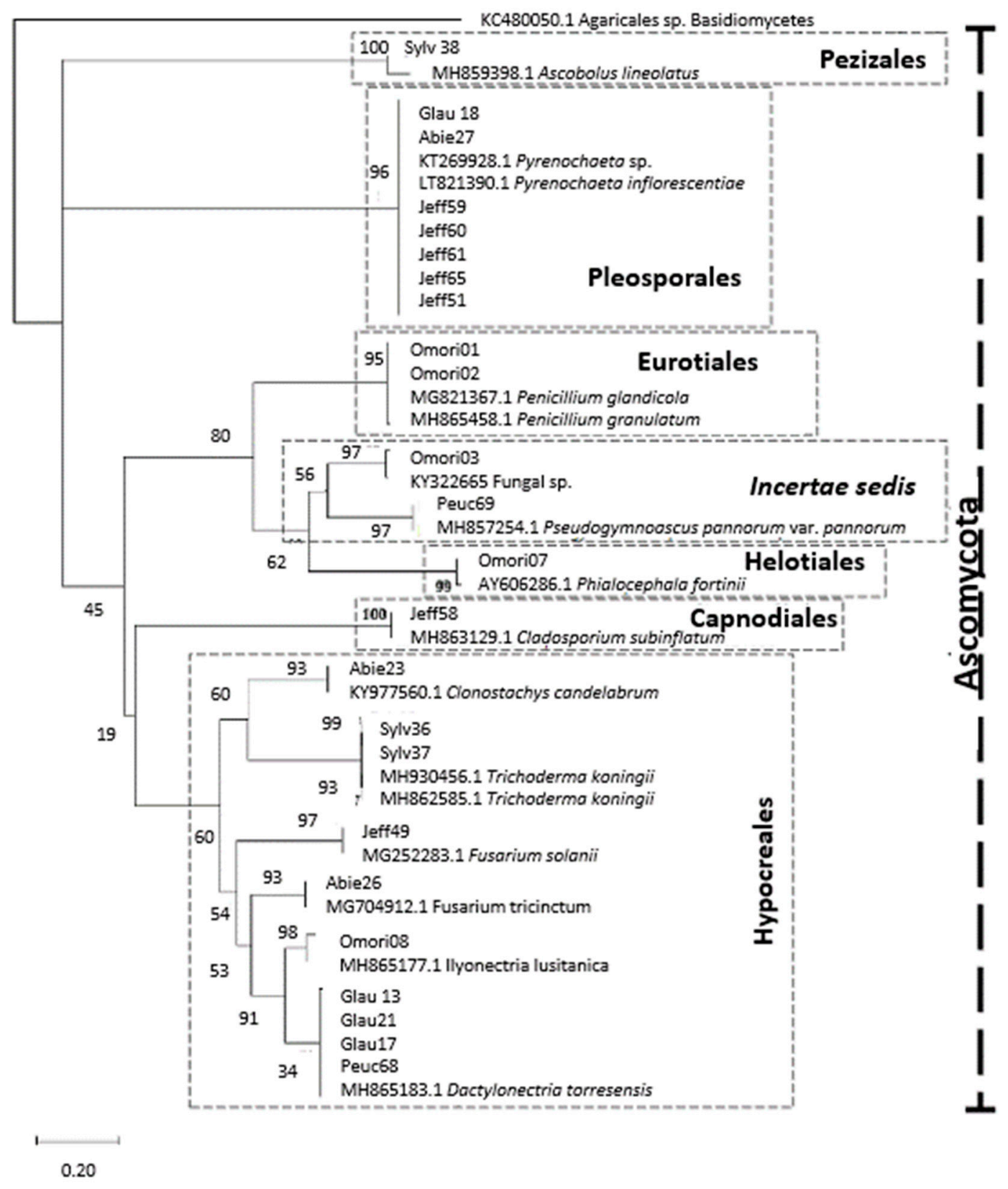

Figure 4. Molecular phylogenetic analysis by maximum likelihood (ML) based on concatenated ITS sequences. The percentage of replicate trees in which the associated taxa clustered together in the bootstrap test are shown next to the branches. Also indicated are the orders to which the samples belong to (dashed rectangles w/descriptions), the phylum (dashed vertical bar), and the outgroup taxon (the Basidiomycete KC480050.1 Agaricales sp. isolated from P. abies by Terhonen et al. [19]. 
The phylogeny was well-resolved up to the species level (Figure 4), with the nodes identifying species relatives featuring strong bootstrap support. Resolution was poorer at the higher taxonomic levels, as the node support was weaker, but yielded 13 distinct clades in total (i.e., lower bootstrap values, Figure 4). Root fungal endophytes belonged to the phylum, Ascomycota, and to the classes, Ascomycetes, Dothideomycetes, Eurotiomycetes, Leotiomycetes, Pezizomycetes, and Sordariomycetes (Table 2). A majority of the identified taxa fell under the orders, Hypocreales and Pleosporales (Table 2, Figure 4). Two taxa were identified as belonging to Eurotiales. One taxa in the orders, Capnodiales, Helotiales, and Pezizales, was also identified.

\subsection{Antagonisms Assay}

The antagonism assay identified 26 of the 65 root endophytes as being statistically successful antagonists against the pathogen, $H$. parviporum (Table 4). None of the assayed samples displayed statistically significant antagonism on day 3 . Half the successful samples (13/26) displayed statistically significant antagonism on day 7 , and 19/26 samples displayed statistically significant antagonism on day 10. Only six samples showed statistically significant antagonism on both days 7 and 10 . These samples were Dactylonectria sp. (Glauc15), Pyrenochaeta sp. (Glauc18 and Sitch48), Fungal sp. (Omori03), Fusarium sp. (Jeff50), and unknown (Sitch46). Pinus jeffreyi was the host with the largest number of successful antagonist root endophytes (9 samples), followed by Pinus sitchensis (6 samples), Picea omori (5 samples), Picea glauca (4 samples), and Picea abies (2 samples) (Table 4).

Table 4. Root endophytes identified as successful antagonists against the pathogen, $H$. parviporum, in the antagonism assay. These samples were identified on the basis of the significance of a t-test ( $p$-value $=0.05$ ) comparing the mean spherical index of their pathogen partners ( $n=3$ trials) with the mean spherical index of the pathogen controls $(n=12)$.

\begin{tabular}{|c|c|c|c|c|c|}
\hline \multirow{2}{*}{ Sample ID } & \multirow{2}{*}{ Host } & \multirow{2}{*}{ Identification } & \multicolumn{3}{|c|}{ Sampling Time (days) ${ }^{a}$} \\
\hline & & & 3 & 7 & 10 \\
\hline Abie25 & Picea abies & Fusarium sp. & $\mathrm{N}$ & $\mathrm{Y}$ & $\mathrm{N}$ \\
\hline Abie29 & Picea abies & Unknown & $\mathrm{N}$ & $\mathrm{N}$ & $\mathrm{Y}$ \\
\hline Glauc15 & Picea glauca & Dactylonectria sp. & $\mathrm{N}$ & $\mathrm{Y}$ & Y \\
\hline Glauc19 & Picea glauca & Dactylonectria sp. & $\mathrm{N}$ & $\mathrm{N}$ & Y \\
\hline Glauc13 & Picea glauca & Dactylonectria sp. & $\mathrm{N}$ & $\mathrm{Y}$ & $\mathrm{N}$ \\
\hline Glauc18 & Picea glauca & Pyrenochaeta sp. & $\mathrm{N}$ & $\mathrm{Y}$ & $\mathrm{Y}$ \\
\hline Omori01 & Picea omorika & Penicillium sp. & $\mathrm{N}$ & $\mathrm{Y}$ & $\mathrm{N}$ \\
\hline Omori03 & Picea omorika & Fungal sp. & $\mathrm{N}$ & $\mathrm{Y}$ & $\mathrm{Y}$ \\
\hline Omori07 & Picea omorika & PAC $^{\mathrm{b}}$ & $\mathrm{N}$ & $\mathrm{N}$ & Y \\
\hline Omori08 & Picea omorika & Ilyonectria sp. & $\mathrm{N}$ & $\mathrm{Y}$ & $\mathrm{N}$ \\
\hline Omori06 & Picea omorika & Fungal sp. & $\mathrm{N}$ & $\mathrm{Y}$ & $\mathrm{N}$ \\
\hline Jeff50 & Pinus jeffreyi & Fusarium sp. & $\mathrm{N}$ & $\mathrm{Y}$ & $\mathrm{Y}$ \\
\hline Jeff55 & Pinus jeffreyi & Fusarium sp. & $\mathrm{N}$ & $\mathrm{N}$ & $\mathrm{Y}$ \\
\hline Jeff58 & Pinus jeffreyi & Fusarium sp. & $\mathrm{N}$ & $\mathrm{N}$ & Y \\
\hline Jeff62 & Pinus jeffreyi & Pyrenochaeta sp. & $\mathrm{N}$ & $\mathrm{N}$ & Y \\
\hline Jeff63 & Pinus jeffreyi & Pyrenochaeta sp. & $\mathrm{N}$ & $\mathrm{N}$ & Y \\
\hline Jeff64 & Pinus jeffreyi & Unknown & $\mathrm{N}$ & $\mathrm{N}$ & $\mathrm{Y}$ \\
\hline Jeff51 & Pinus jeffreyi & Pyrenochaeta sp. & $\mathrm{N}$ & $\mathrm{Y}$ & $\mathrm{N}$ \\
\hline Jeff56 & Pinus jeffreyi & Cladosporium sp. & $\mathrm{N}$ & $\mathrm{Y}$ & $\mathrm{N}$ \\
\hline Jeff65 & Pinus jeffreyi & Pyrenochaeta sp. & $\mathrm{N}$ & $\mathrm{N}$ & $\mathrm{Y}$ \\
\hline Sitch40 & Pinus sitchensis & Pyrenochaeta sp. & $\mathrm{N}$ & $\mathrm{N}$ & $\mathrm{Y}$ \\
\hline Sitch41 & Pinus sitchensis & Pyrenochaeta sp. & $\mathrm{N}$ & $\mathrm{N}$ & $\mathrm{Y}$ \\
\hline Sitch42 & Pinus sitchensis & Unknown & $\mathrm{N}$ & $\mathrm{N}$ & $\mathrm{Y}$ \\
\hline Sitch46 & Pinus sitchensis & Unknown & $\mathrm{N}$ & $\mathrm{Y}$ & Y \\
\hline Sitch47 & Pinus sitchensis & Pyrenochaeta sp. & $\mathrm{N}$ & $\mathrm{N}$ & Y \\
\hline Sitch 48 & Pinus sitchensis & Pyrenochaeta sp. & $\mathrm{N}$ & $\mathrm{Y}$ & $\mathrm{Y}$ \\
\hline
\end{tabular}

a ' $\mathrm{Y}$ ' is statistically significant, ' $\mathrm{N}$ ' is insignificant (for $p$-value $=0.05) .{ }^{\mathrm{b}}$ PAC: Phialocephala fortinii s.l.- Acephala applanata species complex.

Assuming that smaller values of $\alpha / \beta$ (i.e., $\alpha / \beta \rightarrow 0$ ) for the pathogen indicate more successful root endophyte antagonists (Figures 3 and 5), the endophyte, Cladosporium sp. (Jeff56), from the host, 
Pinus jeffreyi, is the most successful antagonist in the sample set 7 days after the start of the experiment (pathogen spherical index $0.74 \pm 0.13$, endophyte spherical index $1.04 \pm 0.03$ ). Similarly, all averages of the spherical indices of all antagonists' root endophytes with statistically significant effects against the pathogen, H. parviporum, were identified with the R-script (Supplementary Files 1 and 2). To study the temporal stability of the antagonism of samples that yielded statistically significant results on both days 7 and 10, the ratios of their mean spherical indices (i.e., MEAN (pathogen spherical index)/MEAN (endophyte spherical index) for every sample) from both time points of measurement were plotted and visualized (Figure 5).

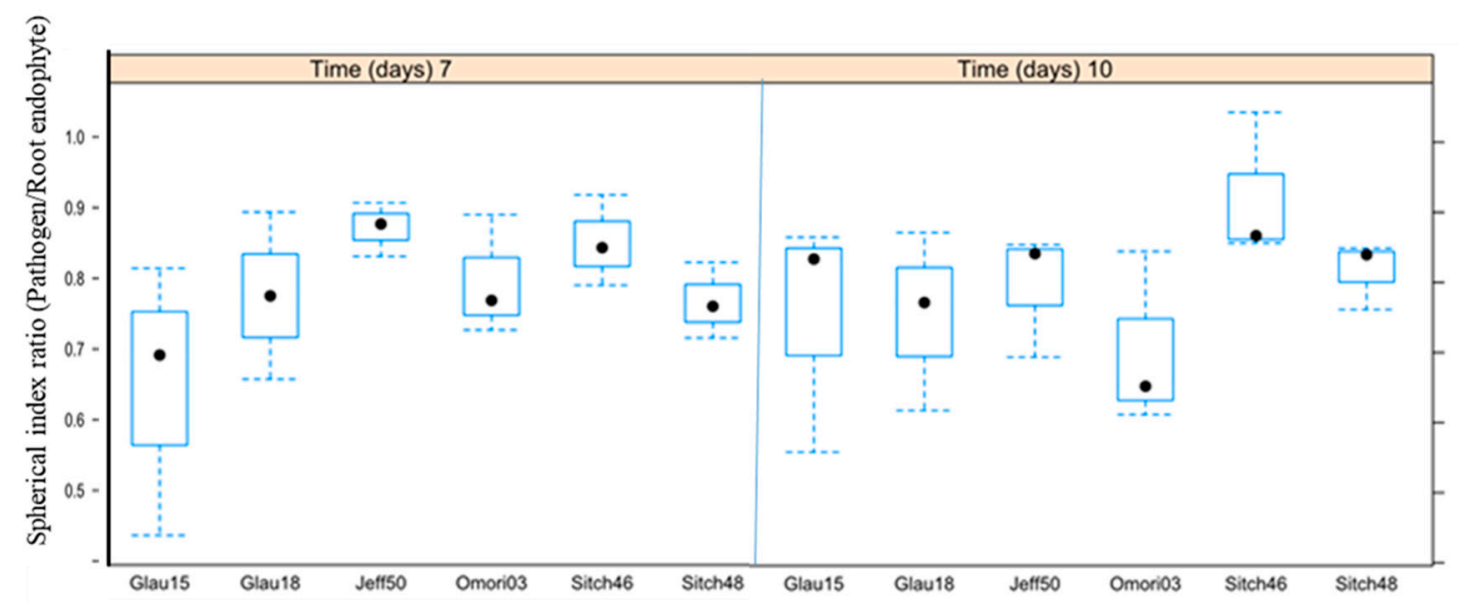

Figure 5. Ratios of the mean spherical indices of the pathogen over its antagonistic partner from day 7 and day 10 measurements of the antagonism assay visualized side-by-side in box-and-whisker plots (solid black circles-medians). Samples shown here are only those which displayed statistically significant antagonism on both days of measurement.

\section{Discussion}

Fungal root endophytes could not be isolated from $P$. pungens. It is unlikely that this conifer species hosts no endophytes. Hence, it is plausible to suggest the presence of uncultivable root endophytes in this particular species, by which the methodology used in this study is unable to recover them [58,59]. This experimental constraint is consolidated by the fact that no relevant information on the abundances and diversity of this conifer's root fungal endophyte community is currently available in the literature. The overall community composition observed in this study greatly differs from other studies of conifer roots $[19,20,24,60,61]$. This study encountered only a single PAC species (from P. omorika, sample Omori07). This contrasts with previous studies that assume that those DSEs-especially members of the PAC - are predominant and abundant among coniferous hosts [15,19-21,24,31,33,34,62]. This result is of special relevance since no PAC species were recovered from well-studied hosts, such as $P$. abies and P. sylvestris. Taking into account that the samples in this study were collected from a non-forest environment, a botanical garden, one explanation could be that the environment influences the composition of endophytic assemblage [63,64]. However, the methodological approach used for the assessment of endophytes' antagonism against $H$. parviporum is methodologically robust. This enables the identification of endophytes that represent potential candidates for future investigations in the context of host-enhancement effects and biocontrol applications.

Species in the genus, Cladosporium, are common endophytes also found on conifer hosts $[65,66]$. The Cladosporium sp. identified in this study (sample Jeff56) also appears to impart a benefit to its host (P. jeffreyi) as it was the most successful antagonist against $H$. parviporum in this study (Table 4; Figure 5). The fungal endophyte, Clonostachys sp., was identified in the roots of Picea glauca. While there are no known instances of this specific root endophyte-host pairing, Clonostachys itself is a well-known root endophyte genus with some species imparting potential benefits to the host plant [67,68]. However, 
in this study, it was not a successful antagonist against the root rot pathogen (Table 4). Interestingly, several occurrences of the Cylindrocarpon-like pathogenic fungus, Dactylonectria sp. (best match Dactylonectria torresensis), were found in this study (in P. glauca and P. peuce, respectively), in which the sample, Glauc13, was one of the successful antagonists of $H$. parviporum. This fungus has been reported as the cause of root rot and decline in host health in strawberry, raspberry, olive trees, and in apple orchards [69-71]. Although species from the genus, Dactylonectria, have been encountered in European old-growth forests [72], no study has reported the presence of this genus in Picea or Pinus before. Fusarium spp. were recovered from multiple hosts (Table 2). Fusarium is a well-documented and ubiquitous root endophyte-containing genus [73-75] of which some species are pathogenic upon their hosts [76]. The results obtained in this study demonstrated that some Fusarium strains proved to be successful in the antagonism assay (Table 4). The Ilyonectria was also encountered in this study (in P. omorika). This is a widely-occurring genus of endophytic fungi [77-80] and at least one member has also been found in P. glauca [81]. Thus, this study is also likely the first time a member of this genus has been recorded in P. omorika. Ilyonectria spp. are also among frequently occurring non-DSE root endophytes. Whether the presence of these fungi in the hosts from this study is pathogenic or beneficial has yet to be defined. The results from this study indicates that the Ilyonectria (isolate Omori08) is a good antagonist of H. parviporum, suggesting that it could compete for niche space with other fungi [82].

Penicillium is a genus of well-known root endophytes that include non-DSE species found in grasses [83], orchids [67], and woody plants [84]. Penicillium spp. are also encountered in the roots of conifer hosts [85]. One Penicillium spp. (sample Omori01) proved to be a successful antagonist against H. parviporum (Table 4). This sample's closest Penicillium relative is P. glandicola, which was only recently revealed as an endophyte in the cactus, Opunita ficus-indica [86]. Pseudogymnoascus sp. in this study was the only sample isolated from P. peuce. Pseudogymnococcus spp. are well-known root endophytes recovered from a variety of hosts, including Ericaceae, Pinus, and Picea [87-89]. Pyrenochaeta is a genus of fungi that contains several DSEs in grasses [83], shrubs [90], and woody species [42,62]. Although a Pyrenochaeta species was reported as an endophyte evoking inhibition of growth in the ash dieback pathogen, Hymenoscyphus fraxineus [91] —indicating that it can be a beneficial endophyte to its host—it has never before been reported as a conifer endophyte. Pyrenochaeta spp. have only been reported in conifers in the role of fungal decomposers of dead wood [92]. In this study, not only Pyrenochaeta spp. have been found in the roots of multiple host species (P. abies, P. glauca, P. sitchensis, and Pinus jeffreyi, Table 2), but we also observed they can be successful antagonists against $H$. parviporum (Table 4). The Pyrenochaeta sp. (Glauc18 and Sitch48) exhibited statistically significant antagonism on both day 7 and day 10 of measurement (Table 4). Thus, the genus, Pyrenochaeta, may hold interesting possibilities for the biocontrol of pathogenicity in conifer hosts. Trichoderma is a genus of well-known endophytes found in orchids [93], herbaceous plants [94], woody species [95], and conifer hosts [96]. Trichoderma sp. were found in this study from $P$. sylvestris. None of the isolates, however, were an effective antagonist against $H$. parviporum, indicating that Trichoderma in the roots does not play a defensive role against this pathogen. Pezizales sp. observed in this study are also a known root endophyte of conifer hosts as at least one member of this order has been encountered in a conifer previously [62].

Molecular phylogenetic analysis by maximum likelihood (ML) based on concatenated ITS sequences (Figure 4) suggests that the unidentified fungal sp. (Omori03) is likely a close relative of Pseudogymnoascus, indicating that this fungus might belong to the Ascomycetes class. Unfortunately, the node support for the branches from which these relationships were inferred is $<90 \%$, so a final conclusion in the absence of other corroborating data cannot be made. This isolate, fungal sp. (Omori03), was one of the strongest antagonists against $H$. parviporum as it displayed statistically significant antagonism on both day 7 and day 10 of measurement (Table 4). The only PAC species was isolated from the host, P. omorika. The screened literature does not contain any records of the PAC occurring in P. omorika, making our result the first confirmation of the species complex' presence in the roots of this conifer species. This PAC species was also found to be a strong antagonist against $H$. parviporum. With 
regards to PAC species as antagonist candidates, the PAC species identified in this study (Omori07) did offer above-average antagonism to $H$. parviporum, but only on day 10 of measurement (Table 4).

In theory, assuming strength by variety and numbers, $P$. jeffreyi with nine successful root endophytic antagonists would be the best protected tree species against H. parviporum. Hence, we can assume a possible correlation between hosting a greater number of antagonist endophytes and level of defensive capabilities against root pathogens. This, however, remains a hypothesis and requires validation for further confirmation, especially as $P$. jeffreyi is not the main host tree of H. parviporum [35]).

Root fungal endophytes are important co-inhabitants of the rhizosphere of coniferous host species. This study has identified a variety of DSE and non-DSE root endophytes from coniferous hosts, including undiscovered root fungal endophyte diversity (e.g., in P. omorika). The antagonism assays performed indicate that potential antagonist root endophytes against $H$. parviporum can be found in a wide variety of coniferous hosts, and that some of these antagonists may also be suitable for long-term biocontrol of the pathogen due to their temporally stable and persistent antagonism. The results of this study also indicate that Cladosporium sp. and Pyrenochaeta sp. are very strong antagonists to $H$. parviporum under laboratory conditions in different ways. Cladosporium sp. did not exhibit temporally persistent antagonism, and while Pyrenochaeta sp. exhibited temporally persistent antagonism, it was not the strongest antagonist. Results established in this paper and the surveyed literature demonstrate that the endophyte-host interactions are complex and affect a wide variety of interactions [5,97], and that even pathogenic fungi (e.g., Dactylonectria) can act as successful antagonists against other pathogens (e.g., H. parviporum), offering protection to the colonized hosts in the process. Schlegel et al. [98] demonstrated that there is probably no clear-cut distinction between a pathogenic endophyte and a mutualistic one, with the endophyte likely switching roles seamlessly as environmental and host-associated factors vary [99]. The factors affecting the antagonist-pathogen relationship also need to be fully elucidated. In addition, the mechanisms mediating these interactions are also not fully understood nor generalized [62]. It was only recently demonstrated experimentally that root endophytes safeguard hosts from root pathogens by quickly occupying the newly growing roots [8]. In this context, antagonistic endophytes as biocontrol measures offer an enticing alternative to chemical methods in forestry [5]. Successful use of root fungal endophytes as biocontrol agents would thus require a thorough understanding of the endophyte-host relationship, the endophyte-pathogen relationship, the host-pathogen relationship, and the influence of environmental factors on these relationships.

Only six of the 65 root endophyte samples displayed statistically significant antagonism on both time points, 7 and 10 days, of the assay. This is indicative of a temporal aspect to the antagonism under this study's experimental conditions-namely, that in a purely 1 vs. 1 scenario with limited space and nutrient availability, a root endophyte might be initially effective against a pathogen only for its antagonistic ability to falter later where the pathogen is potentially the better competitor/survivor under a more resource-constrained situation. With this in mind, selection of endophytes for potential biocontrol applications should then take into account the temporal aspects of the antagonism offered by the fungus. The temporal aspects primarily relate to the instantaneous stability of the antagonism (i.e., there must be minimal variation in the measurable antagonistic effects against the pathogen over time) and to the persistence of the antagonistic effect (i.e., the antagonistic effect must not taper off with time). In the experimental context, this implies that promising candidates from initial, short-term antagonism screenings should then be subjected to extended screening (preferably over multiple years) under lab and field conditions.

\section{Conclusions}

Root endophytes are effective antagonists against $H$. parviporum, suggesting that they may be of benefit to their host tree(s), should these endophytes form either mutualistic or commensalistic relationships with the host tree. On the other hand, two types of pathogenic fungi were also recovered as root endophytes, with some occurrences of them actually being good antagonists against $H$. parviporum (Table 4). Further, it is also possible that the sampled trees host entirely different root endophytes 
compared to their forest counterparts, as these were old, mature trees situated in a botanical garden. Nonetheless, these results imply that there is no simplistic picture of the root endophyte-host tree relationship, and that these interactions need to be investigated in detail with a more all-encompassing range of methodologies on a case-by-case basis. The mechanistic implications of the presence of the discovered root endophytes upon their respective hosts are beyond the scope of this study. In conclusion, this study identified the root fungal endophytes of several conifer hosts, which demonstrated successful antagonism against the white rot pathogen, $H$. parviporum. The data, conclusions, and inferences generated by this study will serve as the basis for executing future investigations into their potential for acting as biocontrol agents against root pathogens.

Supplementary Materials: The following are available online at http://www.mdpi.com/2076-2607/7/4/102/s1. Word file S1: \#R script for identification of successful conifer root-associated fungal endophyte antagonists against Heterobasidion parviporum based on in vitro dual-culture assays, Excel file S2: New R-based methodology to optimize the identification of root endophytes against Heterobasidion parviporum.

Author Contributions: L.R. collected the samples, performed the laboratory experiments and analyzed the data. L.R. wrote the R-script and the first draft. E.T. designed the experimental protocol, conceived the experiment, and contributed to the final draft. K.B. advised and contributed on the experimental protocols, and contributed to the writing of the manuscript.

Funding: This research was funded by Faculty of Forest Sciences and Forest Ecology, Georg-August-Universität Göttingen, Germany.

Acknowledgments: We would like to thank Julia Quintana and Susanna Keriö for valuable comments on the manuscript. We are obliged to Xenia Yeoh Hao-Yi for kindly improving the manuscript as a native English speaker.

Conflicts of Interest: The authors declare no conflict of interest.

\section{References}

1. Carroll, G. Fungal Endophytes in Stems and Leaves: From Latent Pathogen to Mutualistic Symbiont. Ecology 1988, 69, 2-9. [CrossRef]

2. Saikkonen, K.; Faeth, S.H.; Helander, M.; Sullivan, T.J. Fungal endophytes. A continuum of interactions with host plants. Annu. Rev. Ecol. Syst. 1998, 29, 319-343.

3. Clay, K. Fungi and the food of the gods. Nature 2004, 427, 401-402. [CrossRef]

4. Petrini, O. Fungal Endophytes of Tree Leaves. In Microbial Ecology of Leaves; Andrews, J.H., Hirano, S.S., Eds.; Springer: New York, NY, USA, 1991; pp. 179-197.

5. Terhonen, E.; Blumenstein, K.; Kovalchuk, A.; Asiegbu, F.O. Forest Tree Microbiomes and associated Fungal Endophytes: Functional Roles and Impact on Forest Health. Forests 2019, 10, 42. [CrossRef]

6. Tellenbach, C.; Sieber, T.N. Do colonization by dark septate endophytes and elevated temperature affect pathogenicity of oomycetes? FEMS Microbiol. Ecol. 2012, 82, 157-168. [CrossRef] [PubMed]

7. Martín, J.A.; Witzell, J.; Blumenstein, K.; Rozpedowska, E.; Helander, M.; Sieber, T.N.; Gil, L. Resistance to Dutch Elm Disease Reduces Presence of Xylem Endophytic Fungi in Elms (Ulmus spp.). PLoS ONE 2013, 8, e56987.

8. Terhonen, E.; Sipari, N.; Asiegbu, F.O. Inhibition of phytopathogens by fungal root endophytes of Norway spruce. Biol. Control 2016, 99, 53-63. [CrossRef]

9. Jumpponen, A.; Trappe, J.M. Performance of Pinus contorta inoculated with two strains of root endophytic fungus, Phialocephala fortinii: Effects of synthesis system and glucose concentration. Can. J. Bot. 1998, 76, 1205-1213.

10. Newsham, K.K. A meta-analysis of plant responses to dark septate root endophytes. New Phytol. 2011, 190, 783-793. [CrossRef]

11. Vohník, M.; Lukančič, S.; Bahor, E.; Regvar, M.; Vosátka, M.; Vodnik, D. Inoculation of Rhododendron cv. Belle-Heller with two strains of Phialocephala fortinii in two different substrates. Folia Geobot. 2003, 38, 191. [CrossRef]

12. Tellenbach, C.; Grünig, C.R.; Sieber, T.N. Negative effects on survival and performance of Norway spruce seedlings colonized by dark septate root endophytes are primarily isolate-dependent. Environ. Microbiol. 2011, 13, 2508-2517. [CrossRef] 
13. Fernando, A.A.; Currah, R.S. A comparative study of the effects of the root endophytes Leptodontidium orchidicola and Phialocephala fortinii (Fungi Imperfecti) on the growth of some subalpine plants in culture. Can. J. Bot. 1996, 74, 1071-1078. [CrossRef]

14. Jumpponen, A.; Mattson, K.G.; Trappe, J.M. Mycorrhizal functioning of Phialocephala fortinii with Pinus contorta on glacier forefront soil: Interactions with soil nitrogen and organic matter. Mycorrhiza 1998, 7 , 261-265. [CrossRef]

15. Grünig, C.R.; Queloz, V.; Sieber, T.N.; Holdenrieder, O. Dark septate endophytes (DSE) of the Phialocephala fortinii s.l.-Acephala applanata species complex in tree roots: Classification, population biology, and ecology. Botany 2008, 86, 1355-1369. [CrossRef]

16. Mandyam, K.; Jumpponen, A. Seeking the elusive function of the root-colonising dark septate endophytic fungi. Stud. Mycol. 2005, 53, 173-189. [CrossRef]

17. Witzell, J.; Martín, J.A. Phenolic metabolites in the resistance of northern forest trees to pathogens-Past experiences and future prospects. Can. J. For. Res. 2008, 38, 2711-2727. [CrossRef]

18. Schulz, B.J.E.; Boyle, C.J.C.; Sieber, T.N. Microbial Root Endophytes; Soil Biology; Springer: Berlin/Heidelberg, Germany, 2006; ISBN 978-3-540-33525-2.

19. Terhonen, E.; Keriö, S.; Sun, H.; Asiegbu, F.O. Endophytic fungi of Norway spruce roots in boreal pristine mire, drained peatland and mineral soil and their inhibitory effect on Heterobasidion parviporum in vitro. Fungal Ecol. 2014, 9, 17-26. [CrossRef]

20. Kovalchuk, A.; Mukrimin, M.; Zeng, Z.; Raffaello, T.; Liu, M.; Kasanen, R.; Sun, H.; Asiegbu, F.O. Mycobiome analysis of asymptomatic and symptomatic Norway spruce trees naturally infected by the conifer pathogens Heterobasidion spp. Environ. Microbiol. Rep. 2018, 10, 532-541. [CrossRef]

21. Addy, H.D.; Piercey, M.M.; Currah, R.S. Microfungal endophytes in roots. Can. J. Bot. 2005, 83, 1-13. [CrossRef]

22. Jumpponen, A.; Trappe, J.M. Dark septate endophytes: A review of facultative biotrophic root-colonizing fungi. New Phytol. 1998, 140, 295-310. [CrossRef]

23. Queloz, V.; Sieber, T.N.; Holdenrieder, O.; McDonald, B.A.; Grünig, C.R. No biogeographical pattern for a root-associated fungal species complex. Glob. Ecol. Biogeogr. 2011, 20, 160-169. [CrossRef]

24. Sietiö, O.-M.; Tuomivirta, T.; Santalahti, M.; Kiheri, H.; Timonen, S.; Sun, H.; Fritze, H.; Heinonsalo, J. Ericoid plant species and Pinus sylvestris shape fungal communities in their roots and surrounding soil. New Phytol. 2018, 218, 738-751. [CrossRef]

25. Grünig, C.R.; Duò, A.; Sieber, T.N.; Holdenrieder, O. Assignment of species rank to six reproductively isolated cryptic species of the Phialocephala fortinii s.l.-Acephala applanata species complex. Mycologia 2008, 100, 47-67. [CrossRef]

26. Stoyke, G.; Currah, R.S. Endophytic fungi from the mycorrhizae of alpine ericoid plants. Can. J. Bot. 1991, 69, 347-352. [CrossRef]

27. Tejesvi, M.V.; Sauvola, T.; Pirttilä, A.M.; Ruotsalainen, A.L. Neighboring Deschampsia flexuosa and Trientalis europaea harbor contrasting root fungal endophytic communities. Mycorrhiza 2013, 23, 1-10. [CrossRef]

28. Grünig, C.R.; Sieber, T.N.; Rogers, S.O.; Holdenrieder, O. Spatial distribution of dark septate endophytes in a confined forest plot. Mycol. Res. 2002, 106, 832-840. [CrossRef]

29. Grünig, C.R.; McDonald, B.A.; Sieber, T.N.; Rogers, S.O.; Holdenrieder, O. Evidence for subdivision of the root-endophyte Phialocephala fortinii into cryptic species and recombination within species. Fungal Genet. Biol. 2004, 41, 676-687. [CrossRef]

30. Queloz, V.; Duò, A.; Grünig, C.R. Isolation and characterization of microsatellite markers for the tree-root endophytes Phialocephala subalpina and Phialocephala fortinii s.s. Mol. Ecol. Resour. 2008, 8, 1322-1325. [CrossRef]

31. Queloz, V.; Grunig, C.R.; Sieber, T.N.; Holdenrieder, O. Monitoring the spatial and temporal dynamics of a community of the tree-root endophyte Phialocephala fortinii s.1. New Phytol. 2005, 168, 651-660. [CrossRef]

32. Queloz, V.; Duò, A.; Sieber, T.N.; Grünig, C.R. Microsatellite size homoplasies and null alleles do not affect species diagnosis and population genetic analysis in a fungal species complex. Mol. Ecol. Resour. 2010, 10, 348-367. [CrossRef]

33. Sieber, T.N. Endophytic fungi in forest trees: Are they mutualists? Fungal Biol. Rev. 2007, 21, 75-89. [CrossRef]

34. Saikkonen, K. Forest structure and fungal endophytes. Fungal Biol. Rev. 2007, 21, 67-74. [CrossRef] 
35. Garbelotto, M.; Gonthier, P. Biology, epidemiology, and control of Heterobasidion species worldwide. Annu. Rev. Phytopathol. 2013, 51, 39-59. [CrossRef]

36. Gonthier, P.; Garbelotto, M.M.; Nicolotti, G. Seasonal Patterns of Spore Deposition of Heterobasidion Species in Four Forests of the Western Alps. Phytopathology 2005, 95, 759-767. [CrossRef]

37. Lind, M.; Stenlid, J.; Olson, Å. Chapter Twelve-Heterobasidion annosum s.l. Genomics. In Advances in Botanical Research; Martin, F.M., Ed.; Academic Press: London, UK, 2014; Volume 70, pp. 371-396.

38. Asiegbu, F.O.; Adomas, A.; Stenlid, J. Conifer root and butt rot caused by Heterobasidion annosum (Fr.) Bref. s.l. Mol. Plant Pathol. 2005, 6, 395-409. [CrossRef]

39. Korhonen, K. Intersterility groups of Heterobasidion annosum. Commun. Inst. For. Fenn. 1978, 94, 1-25.

40. Capretti, P.; Korhonen, K.; Mugnai, L.; Romagnoli, C. An intersterility group of Heterobasidion annosum specialized to Abies alba. Eur. J. For. Pathol. 1990, 20, 231-240. [CrossRef]

41. Rishbeth, J. Dispersal of Fomes annosus Fr. and Peniophora gigantea (Fr.) massee. Trans. Br. Mycol. Soc. 1959, 42, 243-260. [CrossRef]

42. Isomäki, A.; Kallio, T. Consequences of injury caused by timber harvesting machines on the growth and decay of spruce (Picea abies (L.) Karst.). Acta For. Fenn. 1974, 136, 1-34. [CrossRef]

43. Redfern, D.B.; Stenlid, J. Spore dispersal and infection. In Heterobasidion Annosum: Biology, Ecology, Impact and Control; Woodward, S., Stenlid, J., Karjalainen, R., Hüttermann, A., Eds.; CAB International: Wallingford, UK, 1998; pp. 105-124.

44. Piri, T. The spreading of the $\mathrm{S}$ type of Heterobasidion annosum from Norway spruce stumps to the subsequent tree stand. Eur. J. For. Pathol. 1996, 26, 193-204. [CrossRef]

45. Oliva, J.; Zhao, A.; Zarei, S.; Sedlák, P.; Stenlid, J. Effect of temperature on the interaction between Phlebiopsis gigantea and the root-rot forest pathogen Heterobasidion spp. For. Ecol. Manag. 2015, 340, 22-30. [CrossRef]

46. Piri, T.; Hamberg, L. Persistence and infectivity of Heterobasidion parviporum in Norway spruce root residuals following stump harvesting. For. Ecol. Manag. 2015, 353, 49-58. [CrossRef]

47. Marx, D.H. The influence of ectotrophic mycorrhizal fungi on the resistance of pine roots to pathogenic infections. I. Antagonism of mycorrhizal fungo to root pathogenic fungi and soil bacteria. Phytopathology $1969,59,153-163$.

48. Gardes, M.; Bruns, T.D. ITS primers with enhanced specificity for basidiomycetes-Application to the identification of mycorrhizae and rusts. Mol. Ecol. 1993, 2, 113-118. [CrossRef]

49. Bengtsson-Palme, J.; Ryberg, M.; Hartmann, M.; Branco, S.; Wang, Z.; Godhe, A.; Wit, P.D.; Sánchez-García, M.; Ebersberger, I.; de Sousa, F.; et al. Improved software detection and extraction of ITS1 and ITS2 from ribosomal ITS sequences of fungi and other eukaryotes for analysis of environmental sequencing data. Methods Ecol. Evol. 2013, 4, 914-919. [CrossRef]

50. Kumar, S.; Stecher, G.; Li, M.; Knyaz, C.; Tamura, K. MEGA X: Molecular evolutionary genetics analysis across computing platforms. Mol. Biol. Evol. 2018, 35, 1547-1549. [CrossRef]

51. Altschul, S.F.; Gish, W.; Miller, W.; Myers, E.W.; Lipman, D.J. Basic local alignment search tool. J. Mol. Biol. 1990, 215, 403-410. [CrossRef]

52. Katoh, K.; Standley, D.M. MAFFT Multiple Sequence Alignment Software Version 7: Improvements in Performance and Usability. Mol. Biol. Evol. 2013, 30, 772-780. [CrossRef]

53. Kimura, M. A simple method for estimating evolutionary rates of base substitutions through comparative studies of nucleotide sequences. J. Mol. Evol. 1980, 16, 111-120. [CrossRef]

54. Felsenstein, J. Confidence Limits on Phylogenies: An Approach Using the Bootstrap. Evolution 1985, 39, 783-791. [CrossRef]

55. Stöver, B.C.; Müller, K.F. TreeGraph 2: Combining and visualizing evidence from different phylogenetic analyses. BMC Bioinform. 2010, 11, 7. [CrossRef] [PubMed]

56. Blumenstein, K. Endophytic Fungi in Elms: Implications for the Integrated Management of Dutch Elm Disease. Ph.D. Thesis, Swedish University of Agricultural Sciences, Alnarp, Sweden, 2016.

57. Martín, J.A.; Macaya-Sanz, D.; Witzell, J.; Blumenstein, K.; Gil, L. Strong in vitro antagonism by elm xylem endophytes is not accompanied by temporally stable in planta protection against a vascular pathogen under field conditions. Eur. J. Plant Pathol. 2015, 142, 185-196. [CrossRef]

58. Sun, X.; Guo, L.-D. Endophytic fungal diversity: Review of traditional and molecular techniques. Mycology 2012, 3, 65-76. 
59. Siddique, A.B.; Khokon, A.M.; Unterseher, M. What do we learn from cultures in the omics age? High-throughput sequencing and cultivation of leaf-inhabiting endophytes from beech (Fagus sylvatica L.) revealed complementary community composition but similar correlations with local habitat conditions. MycoKeys 2017, 20, 1-16. [CrossRef]

60. Lazarević, J.; Menkis, A. Fungi inhabiting fine roots of Pinus heldreichii in the Montenegrin montane forests. Symbiosis 2018, 74, 189-197. [CrossRef]

61. Ahlich, K.; Sieber, T.N. The profusion of dark septate endophytic fungi in non-ectomycorrhizal fine roots of forest trees and shrubs. New Phytol. 1996, 132, 259-270. [CrossRef]

62. Sieber, T.N.; Grünig, C.R. Fungal root endophytes. In Plant Roots: The Hidden Half, 4th ed.; Eshel, A., Beeckman, T., Eds.; CRC Press LLC: Boca Raton, FL, USA, 2013; pp. 38.1-38.49.

63. Grünig, C.R.; Duò, A.; Sieber, T.N. Population genetic analysis of Phialocephala fortinii s.l. and Acephala applanata in two undisturbed forests in Switzerland and evidence for new cryptic species. Fungal Genet. Biol. 2006, 43, 410-421. [CrossRef]

64. Stroheker, S.; Dubach, V.; Queloz, V.; Sieber, T.N. Resilience of Phialocephala fortinii s.l.-Acephala applanata communities-Effects of disturbance and strain introduction. Fungal Ecol. 2018, 31, 19-28. [CrossRef]

65. Bensch, K.; Braun, U.; Groenewald, J.Z.; Crous, P.W. The genus Cladosporium. Stud. Mycol. 2012, 72, 1-401. [CrossRef]

66. Paul, N.C.; Yu, S.H. Two species of endophytic Cladosporium in Pine trees in Korea. Mycobiology 2008, 36, 211-216. [CrossRef]

67. Yuan, Z.; Chen, Y.; Yang, Y. Diverse non-mycorrhizal fungal endophytes inhabiting an epiphytic, medicinal orchid (Dendrobium nobile): Estimation and characterization. World J. Microbiol. Biotechnol. 2009, 25, 295. [CrossRef]

68. Sutton, J.C.; Liu, W.; Ma, J.; Brown, W.G.; Stewart, J.F.; Walker, G.D. Evaluation of the fungal endophyte Clonostachys rosea as an inoculant to enhance growth, fitness and productivity of crop plants. Acta Hortic. 2008, 782, 279-286. [CrossRef]

69. Manici, L.M.; Kelderer, M.; Caputo, F.; Saccà, M.L.; Nicoletti, F.; Topp, A.R.; Mazzola, M. Involvement of Dactylonectria and Ilyonectria spp. in tree decline affecting multi-generation apple orchards. Plant Soil 2018, 425, 217-230. [CrossRef]

70. Weber, R.W.S.; Entrop, A.-P. Dactylonectria torresensis as the Main Component of the Black Root Rot Complex of Strawberries and Raspberries in Northern Germany. Erwerbs-Obstbau 2017, 59, 157-169. [CrossRef]

71. Nigro, F.; Antelmi, I.; Sion, V.; Parente, P.; Pacifico, A. First Report of Dactylonectria torresensis Causing Foot and Root Rot of Olive Trees. Plant Dis. 2018. [CrossRef]

72. Jankowiak, R.; Stępniewska, H.; Szwagrzyk, J.; Bilański, P.; Gratzer, G. Characterization of Cylindrocarpon-like species associated with litter in the old-growth beech forests of Central Europe. For. Pathol. 2016, 46, 582-594. [CrossRef]

73. Demers, J.E.; Gugino, B.K.; Jiménez-Gasco, M.d.M. Highly Diverse Endophytic and Soil Fusarium oxysporum Populations Associated with Field-Grown Tomato Plants. Appl. Environ. Microbiol. 2015, 81, 81-90. [CrossRef]

74. González-Teuber, M.; Vilo, C.; Bascuñán-Godoy, L. Molecular characterization of endophytic fungi associated with the roots of Chenopodium quinoa inhabiting the Atacama Desert, Chile. Genom. Data 2017, 11, 109-112. [CrossRef]

75. Rodriguez, R.J.; White, J.F., Jr.; Arnold, A.E.; Redman, R.S. Fungal endophytes: Diversity and functional roles: Tansley review. New Phytol. 2009, 182, 314-330. [CrossRef]

76. Castañares, E.; Stenglein, S.A.; Dinolfo, M.I.; Moreno, M.V. Fusarium tricinctum Associated with Head Blight on Wheat in Argentina. Plant Dis. 2010, 95, 496. [CrossRef]

77. Görke, C. Mykozönosen von Wurzel und Stamm von Jungbäumen unterschiedlicher Bestandsbegründungen. Available online: https://www.schweizerbart.de/publications/detail/isbn/9783443590758 (accessed on 28 February 2019).

78. Sieber, T.N. Endophytische Pilze von Winterweizen (Triticum vulgare Vill.): Ein Vergleich Zwischen Weizen aus Gebeiztem und Solchem aus Ungebeiztem Saatgut; ETH Zürich: Zürich, Switzerland, 1985.

79. Stark, C.; Babik, W.; Durka, W. Fungi from the roots of the common terrestrial orchid Gymnadenia conopsea. Mycol. Res. 2009, 113, 952-959. [CrossRef] [PubMed] 
80. Petrini, O.; Fisher, P.; Petrini, L. Fungal endophytes of bracken (Pteridium aquilinum), with some reflections on their use in biological control. Sydowia 1992, 44, 282-293.

81. Cabral, A.; Rego, C.; Nascimento, T.; Oliveira, H.; Groenewald, J.Z.; Crous, P.W. Multi-gene analysis and morphology reveal novel Ilyonectria species associated with black foot disease of grapevines. Fungal Biol. 2012, 116, 62-80. [CrossRef] [PubMed]

82. Blumenstein, K.; Albrectsen, B.R.; Martín, J.A.; Hultberg, M.; Sieber, T.N.; Helander, M.; Witzell, J. Nutritional niche overlap potentiates the use of endophytes in biocontrol of a tree disease. BioControl 2015, 60, 655-667. [CrossRef]

83. Sánchez Márquez, S.; Bills, G.F.; Domínguez Acuña, L.; Zabalgogeazcoa, I. Endophytic mycobiota of leaves and roots of the grass Holcus lanatus. Fungal Divers. 2010, 41, 115-123. [CrossRef]

84. Nicoletti, R.; Fiorentino, A.; Scognamiglio, M. Endophytism of Penicillium _Species in Woody Plants. TOMYCJ 2014, 8, 1-26. [CrossRef]

85. Courtois, H. The mycoflora in the crown region and rhizosphere of Norway spruce (Picea abies), and its significance for interpreting forest decline symptoms. Angew. Bot. 1990, 64, 381-392.

86. Bezerra, J.D.P.; Santos, M.G.S.; Svedese, V.M.; Lima, D.M.M.; Fernandes, M.J.S.; Paiva, L.M.; Souza-Motta, C.M. Richness of endophytic fungi isolated from Opuntia ficus-indica Mill. (Cactaceae) and preliminary screening for enzyme production. World J. Microbiol. Biotechnol. 2012, 28, 1989-1995. [CrossRef] [PubMed]

87. Allen, T.R.; Millar, T.; Berch, S.M.; Berbee, M.L. Culturing and direct DNA extraction find different fungi from the same ericoid mycorrhizal roots. New Phytol. 2003, 160, 255-272. [CrossRef]

88. Menkis, A.; Vasaitis, R. Fungi in Roots of Nursery Grown Pinus sylvestris: Ectomycorrhizal Colonisation, Genetic Diversity and Spatial Distribution. Microb. Ecol. 2011, 61, 52-63. [CrossRef]

89. Summerbell, R.C. Microfungi associated with the mycorrhizal mantle and adjacent microhabitats within the rhizosphere of black spruce. Can. J. Bot. 1989, 67, 1085-1095. [CrossRef]

90. An, H.; Liu, Y.; Zhao, X.; Huang, Q.; Yuan, S.; Yang, X.; Dong, J. Characterization of cadmium-resistant endophytic fungi from Salix variegata Franch. in Three Gorges Reservoir Region, China. Microbiol. Res. 2015, 176, 29-37. [CrossRef]

91. Schlegel, M.; Dubach, V.; von Buol, L.; Sieber, T.N. Effects of endophytic fungi on the ash dieback pathogen. FEMS Microbiol. Ecol. 2016, 92. [CrossRef]

92. Kwaśna, H.; Mazur, A.; abędzki, A.; Kuźmiński, R.; akomy, P. Communities of fungi in decomposed wood of oak and pine. For. Res. Pap. 2016, 77, 261-275. [CrossRef]

93. Vaz, A.B.M.; Mota, R.C.; Bomfim, M.R.Q.; Vieira, M.L.A.; Zani, C.L.; Rosa, C.A.; Rosa, L.H. Antimicrobial activity of endophytic fungi associated with Orchidaceae in Brazil. Can. J. Microbiol. 2009, 55, 1381-1391. [CrossRef] [PubMed]

94. Xia, X.; Lie, T.K.; Qian, X.; Zheng, Z.; Huang, Y.; Shen, Y. Species Diversity, Distribution, and Genetic Structure of Endophytic and Epiphytic Trichoderma Associated with Banana Roots. Microb. Ecol. 2011, 61, 619-625. [CrossRef] [PubMed]

95. Werner, C.; Petrini, O.; Hesse, M. Degradation of the polyamine alkaloid aphelandrine by endophytic fungi isolated from Aphelandra tetragona. FEMS Microbiol. Lett. 1997, 155, 147-153. [CrossRef]

96. Kattner, D.; Schönhar, S. Occurrence of microscopic fungi in fine roots of apparently healthy Norway spruce on various sites. Mitteilungen Verein Für Forstliche Standortskunde Forstpflanzenzüchtung 1990, 35, 39-43.

97. Gan, H.; Churchill, A.C.L.; Wickings, K. Invisible but consequential: Root endophytic fungi have variable effects on belowground plant-insect interactions. Ecosphere 2017, 8, e01710. [CrossRef]

98. Schlegel, M.; Münsterkötter, M.; Güldener, U.; Bruggmann, R.; Duò, A.; Hainaut, M.; Henrissat, B.; Sieber, C.M.K.; Hoffmeister, D.; Grünig, C.R. Globally distributed root endophyte Phialocephala subalpina links pathogenic and saprophytic lifestyles. BMC Genom. 2016, 17, 1015. [CrossRef]

99. Bußkamp, J. Schadenserhebung, Kartierung und Charakterisierung des "Diplodia-Triebsterbens" der Kiefer, Insbesondere des Endophytischen Vorkommens in den Klimasensiblen Räumen und Identifikation von den in Kiefer (Pinus sylvestris) Vorkommenden Endophyten. Ph.D. Thesis, University of Kassel, Kassel, Germany, 2018.

(C) 2019 by the authors. Licensee MDPI, Basel, Switzerland. This article is an open access article distributed under the terms and conditions of the Creative Commons Attribution (CC BY) license (http://creativecommons.org/licenses/by/4.0/). 